\title{
Factors Associated with Early-onset Neonatal Sepsis in Children of Peruvian Military Personnel
}

\section{Factores asociados a sepsis neonatal temprana en niños hijos de personal militar peruano}

César A. Mogollón ${ }^{1}$, Evelyn E. Bautista², Gustavo Hernández-Arriaga ${ }^{3}$, Lotty Bueso-Pineda ${ }^{4}$ Marcos Roberto Tovani-Palone ${ }^{5}$, Christian R. Mejia ${ }^{6}$

\begin{abstract}
Introduction: The risk factors for early-onset neonatal sepsis (EOS) are well known. However, they have still not been evaluated in children of military personnel, which are a special population.

Objective: To determine factors associated with EOS in children of Peruvian military personnel in a hospital.

Materials and Methods: This is an observational, analytical, and retrospective study that included neonates hospitalized in the Neonatal Unit of the Hospital Militar Central, Peru between 2009 and 2017. Data were compiled from clinical history and hospital stay records. Sepsis cases were crosschecked against other variables of interest via generalized linear models.

Results: Out of a total of 2,371 included neonates, 114 neonates were diagnosed with EOS. There was an increased frequency of neonatal sepsis with longer neonatal hospital stay (adjusted prevalence ratio (aPR): 1.21; 95\% confidence interval (Cl): 1.15-1.28; $p<0.001$ ), greater gestational age (aPR: $1.03 ; 95 \% \mathrm{Cl}: 1.01-1.05 ; \mathrm{p}=0.003$ ), and development of urinary tract infection in pregnant women in the third trimester of pregnancy (aPR: $2.27 ; 95 \%$ $\mathrm{Cl}: 1.39-3.73 ; \mathrm{p}=0.003)$. In contrast, there was a lower incidence of neonatal sepsis in female neonates (aPR: $0.64 ; 95 \% \mathrm{Cl}: 0.42-0.99 ; \mathrm{p}=0.044$ ).

Conclusions: The associated factors with EOS in children of Peruvian military personnel were sex, longer neonatal hospital stay, gestational age and development of urinary tract infection in pregnant women during the third trimester of pregnancy. The aforementioned information is significant in describing this neonate population.
\end{abstract}

Keywords: neonatal sepsis, risk factors, neonates, military personnel, Peru

\section{RESUMEN}

Introducción: Los factores de riesgo asociados a sepsis neonatal temprana (EOS) son bien conocidos. Sin embargo, hasta el momento no han sido evaluados en niños hijos de personal militar, los cuales son una población especial.

Objetivo: Determinar los factores asociados a EOS en los hijos de personal militar en un hospital.

Materiales y Métodos: Estudio observacional, analítico y retrospectivo, que incluyó a neonatos hospitalizados en la Unidad de Neonatología del Hospital Militar Central, Perú entre 2009 y 2017. Los datos fueron recopilados de las historias clínicas y del libro de estancia hospitalaria. Los casos de sepsis se compararon con variables de interés a través de modelos lineales generalizados.

Resultados: De un total de 2371 neonatos incluidos en el estudio, 114 neonatos fueron diagnosticados con EOS. Existió una mayor frecuencia de sepsis neonatal asociada a una estancia hospitalaria prolongada (razón de prevalencia ajustada (Rpa): 1,21; intervalo de confianza (IC) 95\%: 1,15-1,28; $p<0,001)$, mayor edad gestacional (RPa: 1,03; IC 95\%: 1,01-1,05; $p=0,003$ ) y infección del tracto urinario en mujeres en el tercer trimestre de gestación (RPa: 2,27; IC 95\%: 1,39-3,73; $p=0,003$ ). En cambio, hubo una menor incidencia de sepsis neonatal en neonatas mujeres (RPa: 0,64; IC 95\%: 0,42-0,99; $\mathrm{p}=0,044)$.

Conclusiones: Los factores de riesgo asociados a EOS en niños hijos de personal militar fueron sexo, larga estancia hospitalaria, edad gestacional y infección del tracto urinario en mujeres en el tercer trimestre de gestación. La información antes mencionada es significativa para describir esta población neonatal.

Palabras clave: sepsis neonatal, factores de riesgo, neonatos, personal militar, Perú

\footnotetext{
Universidad Nacional de Cajamarca, Cajamarca, Peru.

Sociedad Científica de Estudiantes de Medicina de Cajamarca, Universidad

Nacional de Cajamarca, Cajamarca, Peru.

3 Facultad de Medicina y Cirugía, Universidad Católica de Honduras, San Pedro Sula, Honduras.

4 School of Nursing, Trinity Western University, Langley, BC, Canada.

5 Ribeirão Preto Medical School, University of São Paulo, Ribeirão Preto, Brazil.

6 Universidad Continental, Lima, Peru.
}

Correspondence: Christian R. Mejia

Mailing address: Av. Las Palmeras 5713 - Lima 39, Perú.

E-mail: christian.mejia.md@gmail.com

Received: 3 Nov 2018, Accepted: 13 Oct 2019

(C) 2019 by the authors; licensee Modestum Ltd., UK. This article is an open access article distributed under the terms and conditions of the Creative Commons Attribution License (http://creativecommons.org/licenses/by/4.0/). 


\section{INTRODUCTION}

Risk factors for early-onset neonatal sepsis (EOS) include both maternal and neonatal factors, such as maternal age above 35 or below 20 years, prematurity, parity, cesarean delivery, urinary tract infection in the third trimester of pregnancy, and neonate's sex (1). Over the past 30 years, several efforts have been made towards work and practices of clinical science involving thousands of neonates and their families, however no significant improvement has been observed in diagnostic accuracy, clinical management, or results to treatment of neonatal sepsis (2). Consequently, we continue to see symptoms of EOS in different populations prior to the first 7 days of age and/or in cases with infection during the first $72 \mathrm{~h}$ of life (3) according to the definition employed.

Although this issue has been studied based on multiple realities and perspectives to evaluate the different associated factors (4-7), up till now, we found no research in the literature about EOS in the population of military children. In Peru, these children have access to a particular kind of healthcare service, which is exclusive and subsidized by the government. In this sense, new studies involving military children should be helpful in understanding specific risk factors for EOS in this group and in comparison with the general population. Thus, the objective of the present study was to determine factors associated with EOS in children of Peruvian military personnel in a hospital.

\section{MATERIALS AND METHODS}

This analytical cross-sectional study was conducted at the Neonatal Unit of the Hospital Militar Central (HMC) in Peru, which is a referral hospital level III-1 (with national coverage for the Peruvian military). It provides healthcare coverage to military patients and their families. A nonrandomized sampling was performed.

Neonates of both sexes, who were born alive, admitted into the HMC Neonatal Unit, that had a clinical and/or laboratory diagnosis of EOS, with complete data in their clinical history and/or hospital stay records were included in the study. Patients who were not born at the HMC (referred from other healthcare institutions), preterms, and those with incomplete data in their clinical history and/or hospital stay records were excluded. Also, patients with risk of death due to congenital malformations, congenital cardiopathies, tetralogy of Fallot, transposition of the great vessels, interauricular communication, interventricular communication, gastroschisis, omphalocele, myelomeningocele, and esophageal atresia (the exclusion did not exceed $10 \%$ of the data) were excluded in the study.

A sheet was created for data gathering based on the variables of the study. This instrument consisted of 15 items divided into sections. The first section included data on the neonates, such as sex, date of birth, number of weeks at birth, Apgar score, weight on admission and on discharge, and length of hospital stay. The second section included data on EOS diagnosis, jaundice, and macrosomia; while the third part, data on characteristics of the mothers, such as age, number of pregnancies, days of gestation, number of prenatal visits, delivery type, and development of urinary tract infection (UTI) in the third trimester of pregnancy. Furthermore, microscopic urinalysis was used for UTI diagnosis.

The present study results from a project reviewed and approved by the HMC Ethics Committee, (number 34 AA$11 / 8 / \mathrm{HMC} / \mathrm{DADCl}$ ). Upon receiving approval, data were obtained from the period between 2009 and 2017 using the created sheet. To ensure data confidentiality, no sheet or gathered data had any identifying information of the participants. After gathering the data, the filtering and quality control were carried out by one of the study authors.

The statistical analysis was performed in a Microsoft Excel ${ }^{\circledR}$ sheet, version 16.11.1, for Mac. Subsequently, data were exported to the STATA program for Mac ${ }^{\circledR} 14.1$ Statistics/Data Analysis MP - Parallel Edition, where the first descriptive analysis was conducted using the interquartile range/median and absolute/relative frequencies for numerical and categorical variables, respectively. Analytical statistics was employed to obtain the crude prevalence ratio (cPR), adjusted prevalence ratio (aPR), 95\% confidence intervals $(\mathrm{Cl})$, and $\mathrm{p}$-values, all of which were calculated through generalized linear models using the Poisson distribution and log-link function. P-values $<0.05$ were considered statistically significant.

\section{Study Definitions}

EOS was defined as an infection during the first 72 hours of life.

UTI was diagnosed based on the presence of leukocytes (pyuria, defined as $>5-10$ leucocytes/hpf) or bacteria (bacteriuria, $>15$ bacteria/hpf). 
Table 1: Characteristics of neonates treated at the Hospital Militar Central between 2009 and 2017

\begin{tabular}{|c|c|c|}
\hline Variable & $\mathbf{n}$ & $\%$ \\
\hline \multicolumn{3}{|l|}{ Sex } \\
\hline Female & 1159 & 48.8 \\
\hline Male & 1213 & 51.2 \\
\hline \multicolumn{3}{|l|}{ Date of birth } \\
\hline 2009 & 283 & 11.9 \\
\hline 2010 & 266 & 11.2 \\
\hline 2011 & 265 & 11.2 \\
\hline 2012 & 218 & 9.2 \\
\hline 2013 & 259 & 10.9 \\
\hline 2014 & 297 & 12.5 \\
\hline 2015 & 243 & 10.3 \\
\hline 2016 & 288 & 12.2 \\
\hline 2017 & 252 & 10.6 \\
\hline Days of hospitalization* & 3 & $1-32$ \\
\hline \multicolumn{3}{|l|}{ Jaundice } \\
\hline Yes & 174 & 7.3 \\
\hline No & 2197 & 92.7 \\
\hline \multicolumn{3}{|l|}{ Macrosomia } \\
\hline Yes & 76 & 3.2 \\
\hline No & 2295 & 96.8 \\
\hline \multicolumn{3}{|l|}{ Sepsis } \\
\hline Yes & 114 & 4.8 \\
\hline No & 2257 & 95.2 \\
\hline
\end{tabular}

*Median and interquartile range

\section{RESULTS}

Out of a total of 2,585 neonates born at HMC, 2,371 were included in the study. $51.2 \%(1,213)$ were male, $7.3 \%(174)$ had jaundice, 3.2\% (76) had macrosomia, 4.8\% (114) had neonatal sepsis, and the median length of hospital stay was 3 days (Table 1).

The median gestational age was 274 days, while the mothers had a median age of 30 years. All these women had two prior pregnancies and 8 prenatal check-ups were performed for each woman. $69.8 \%$ of them $(1,649)$ did not have prior abortions; however, 23.2\% (548) had at least one abortion. As shown in Table 2,63.8\% of the mothers $(1,484)$ had labor dystocia, $90.8 \%(1,497)$ had cesarean delivery, and $10.1 \%$ (239) had urinary tract infection in the third trimester of pregnancy (Table 2).

In conducting the bivariate analysis of neonatal factors associated with sepsis, the results showed that the neonate's sex $(p=0.003)$ and length of hospital stay within the neonatology unit $(p<0.001)$ were associated with neonatal sepsis (Table 3). 
Table 2: Characteristics of mothers who gave birth to neonates treated at the Hospital Militar Central between 2009 and 2017

\begin{tabular}{|c|c|c|}
\hline Variable & $\mathbf{n}$ & $\%$ \\
\hline Mother's age* & 30 & $15-50$ \\
\hline Days of gestation* & 274 & 211-309 \\
\hline Past pregnancies* & 2 & $1-9$ \\
\hline Prenatal check-ups* & 8 & $0-20$ \\
\hline \multicolumn{3}{|l|}{ Abortion history } \\
\hline None & 1649 & 69.8 \\
\hline One & 548 & 23.2 \\
\hline Two & 131 & 5.5 \\
\hline Three & 33 & 1.4 \\
\hline Four & 3 & 0.1 \\
\hline \multicolumn{3}{|l|}{ Labor dystocia } \\
\hline Yes & 1484 & 63.8 \\
\hline No & 841 & 36.2 \\
\hline \multicolumn{3}{|l|}{ Cesarean delivery } \\
\hline Yes & 1497 & 90.8 \\
\hline No & 151 & 9.2 \\
\hline \multicolumn{3}{|c|}{ UTI in the third trimester of pregnancy } \\
\hline Yes & 239 & 10.1 \\
\hline No & 2132 & 89.9 \\
\hline
\end{tabular}

$\mathrm{UTI}=$ urinary tract infection.

*Median and range

Table 3: Bivariate analysis of neonatal factors associated with sepsis

\begin{tabular}{|c|c|c|c|c|}
\hline \multirow{2}{*}{ Variable } & \multicolumn{2}{|c|}{ Neonatal sepsis N (\%) } & \multirow[t]{2}{*}{ CPR $(95 \% \mathrm{Cl})$} & \multirow[t]{2}{*}{ p-value } \\
\hline & Yes & No & & \\
\hline \multicolumn{5}{|l|}{ Neonate's sex } \\
\hline Female & $40(3.5)$ & $1118(96.5)$ & $0.57(0.39-0.82)$ & 0.003 \\
\hline Male & $71(6.1)$ & 1139 (93.9) & \multicolumn{2}{|c|}{ Comparison category } \\
\hline \multicolumn{5}{|l|}{ Date of birth } \\
\hline 2009 & $17(6.0)$ & $266(94.0)$ & \multicolumn{2}{|c|}{ Comparison category } \\
\hline 2010 & $8(3.0)$ & $258(97.0)$ & $0.50(0.22-1.14)$ & 0.100 \\
\hline 2011 & $17(6.4)$ & $248(93.6)$ & $1.07(0.56-2.05)$ & 0.843 \\
\hline 2012 & $9(4.1)$ & 209 (95.9) & $0.69(0.31-1.51)$ & 0.351 \\
\hline 2013 & $8(3.1)$ & $251(96.9)$ & $0.51(0.23-1.17)$ & 0.113 \\
\hline 2014 & $18(6.1)$ & $279(93.9)$ & $1.01(0.53-1.92)$ & 0.978 \\
\hline 2015 & $12(4.9)$ & $231(95.1)$ & $0.82(0.40-1.69)$ & 0.593 \\
\hline 2016 & $13(4.5)$ & $275(95.5)$ & $0.75(0.37-1.52)$ & 0.426 \\
\hline 2017 & $12(4.8)$ & $240(95.2)$ & $0.79(0.39-1.63)$ & 0.527 \\
\hline Days of hospitalization* & $8(7-9)$ & $3(2-4)$ & $1.23(1.16-1.29)$ & $<0.001$ \\
\hline Jaundice & $10(5.8)$ & $164(94.2)$ & $1.21(0.65-2.28)$ & 0.546 \\
\hline Macrosomia & $3(4.0)$ & $73(96.0)$ & $0.82(0.27-2.51)$ & 0.723 \\
\hline
\end{tabular}

${ }^{*}$ Descriptive values are shown as median (interquartile ranges)

In conducting the bivariate analysis of maternal and delivery factors associated with sepsis, gestational days $(p=0.024)$ and development of urinary tract infection in the third trimester $(p<0.001)$ were associated with sepsis (Table 4).

In conducting the multivariate analysis, there was an increased frequency in neonatal sepsis with longer neonatal hospital stay (aPR, 1.21; 95\% Cl, 1.15-1.28; $\mathrm{p}<0.001)$, greater gestational age $(a P R, 1.03 ; 95 \% \mathrm{Cl}, 1.01-1.05 ; \mathrm{p}=0.003)$, and development of urinary tract infection in the third trimester of pregnancy (aPR, 2.27;95\% Cl, 1.39-3.73; $p=0.003$ ). In contrast, there was a lower incidence of neonatal sepsis in female neonates $(a P R, 0.64 ; 95 \% C l, 0.42-0.99 ; p=0.044)$ (Table 5). 
Table 4: Bivariate analysis of maternal and delivery factors associated with sepsis

\begin{tabular}{|c|c|c|c|c|}
\hline \multirow{2}{*}{ Variable } & \multicolumn{2}{|c|}{ Neonatal sepsis N (\%) } & \multirow[t]{2}{*}{ CPR $(95 \% \mathrm{Cl})$} & \multirow[t]{2}{*}{ p-value } \\
\hline & Yes & No & & \\
\hline Mother's age* & $30(26-33)$ & $31(26-35)$ & $0.97(0.94-1.00)$ & 0.097 \\
\hline Days of gestation* & $277(273-285)$ & $274(268-282)$ & $1.03(1.00-1.05)$ & 0.024 \\
\hline Past pregnancies* & $2(1-3)$ & $2(1-3)$ & $0.90(0.77-1.05)$ & 0.190 \\
\hline Prenatal check-ups* & $7(6-9)$ & $8(6-9)$ & $0.98(0.89-1.08)$ & 0.678 \\
\hline \multicolumn{5}{|l|}{ Abortion history } \\
\hline None & $77(4.7)$ & $1572(95.3)$ & \multicolumn{2}{|c|}{ Comparison category } \\
\hline One & $26(4.7)$ & $522(95.3)$ & $1.02(0.66-1.57)$ & 0.943 \\
\hline Two & $10(7.6)$ & $121(92.4)$ & $1.63(0.87-3.08)$ & 0.129 \\
\hline Three & $1(3.0)$ & $32(97.0)$ & $0.65(0.09-4.53)$ & 0.666 \\
\hline Four & $0(0.0)$ & $3(100.0)$ & Limit & \\
\hline \multicolumn{5}{|l|}{ Labor dystocia } \\
\hline Yes & $77(5.2)$ & $1407(94.8)$ & $1.28(0.86-1.90)$ & 0.215 \\
\hline No & $34(4.0)$ & $807(96.0)$ & \multicolumn{2}{|c|}{ Comparison category } \\
\hline \multicolumn{5}{|l|}{ Cesarean delivery } \\
\hline Yes & $79(5.3)$ & $1418(94.7)$ & $1.14(0.53-2.42)$ & 0.736 \\
\hline No & $7(4.6)$ & $144(95.4)$ & \multicolumn{2}{|c|}{ Comparison category } \\
\hline \multicolumn{5}{|c|}{ UTI in the third trimester of pregnancy } \\
\hline Yes & $23(9.6)$ & $216(90.4)$ & $2.25(1.46-3.49)$ & $<0.001$ \\
\hline No & $91(4.3)$ & $2041(95.7)$ & \multicolumn{2}{|c|}{ Comparison category } \\
\hline
\end{tabular}

$\mathrm{UTI}=$ urinary tract infection.

${ }^{*}$ Descriptive values are shown as median (interquartile ranges)

Table 5: Multivariate analysis of factors associated with neonatal sepsis

\begin{tabular}{llcc}
\hline Variable & aPR & $\mathbf{9 5 \%} \mathbf{C l}$ & P-value \\
\hline Female sex of the neonate & 0.64 & $0.42-0.99$ & 0.044 \\
\hline Days of hospitalization* & 1.21 & $1.15-1.28$ & $<0.001$ \\
\hline Days of gestation* & 1.03 & $1.01-1.05$ & 0.003 \\
\hline UTI in the third trimester of pregnancy & 2.27 & $1.39-3.73$ & $<0.001$ \\
\hline
\end{tabular}

UTI = urinary tract infection.

*Variables were considered quantitative

\section{DISCUSSION}

According to the results of this study, there was an association between development of urinary tract infection in the third trimester of pregnancy and EOS. This could be explained by the consistent evidence found of high frequency of EOS among neonates whose mothers had bacterial infection or colonization during pregnancy (4), following the findings of Gobremedhin, Berhe, and Gebrekirston (2016) (5), and Rojas Espinoza (2014) (6). Moreover, this confirms that each pregnancy trimester has its own risks for the mother and neonate, which is why necessary care must be taken so that the mother-child binomial has a good balance at all times.

However, the total prevalence of EOS was shown to be low, with approximately only one in 20 neonates having a diagnosis consistent with this disease in the 9 years of the study. This number, in turn, is found within the values reported in the literature (1). Despite this low incidence, one must take this into account for appropriate diagnosis and care for this patient group, given that EOS continues to be one of the neonatal pathologies with a higher morbidity rate worldwide. It is estimated that, on a global level, there is an approximate incidence of 3 million cases of neonatal sepsis per year (7), which makes it an important issue in Neonatology Services.

In addition, there are diagnostic challenges in determining EOS, since a positive blood sample continues to be the gold standard (8). Therefore, even with a low prevalence of EOS, it is critical for health care providers to be aware of prevention measures, diagnostic challenges, and the appropriate management to prevent neonatal deaths from EOS at HMC and other military hospitals.

An important result of the present study was also that the mothers had a median age of 30 years. We did not find a related significant correlation, which is consistent with that reported in China, where maternal age $>35$ years is a predisposing factor for EOS (9). According to other authors, such as Daniel Henrique (2017), maternal age $<15$ and $\geq$ 35 years is a predisposing factor for EOS (10), corroborating the findings of Pérez (2015). This researcher reported that that maternal age $\leq 15$ years is a factor associated with EOS (11). 
Furthermore, the median gestational age in our study was 274 days to term. Coral Linares (2014) reported that prematurity <37 weeks is also a risk factor for EOS (12), as did Jajoo et al. (2015) (13) in their study conducted in New Delhi, India, and Softić et al. (2017) in Bosnia and Herzegovina (14).

It is essential to highlight that, according to our results, the median for prenatal check-ups was 8 . The Ministry of Health of Peru recommends a number $\geq 6$ of prenatal check-ups (15). lyo Alberti (2015) reported that fewer than 6 prenatal check-ups is a risk factor for EOS (16).

Another relevant point is the possible cause for the low prevalence of sepsis found by us, which may have occurred because some of the characteristics of the mothers of the studied population were not among the risk factors for sepsis, such as the mother's age and number of prenatal check-ups (without predisposition to EOS in our case). This finding should also be associated with the particularities of this population, as these people obtain government subsidy, are under military discipline, and have a high economic income. However, it is important for health care providers to provide sexual education to such mothers (taking into account risk factors) to be able to prevent the risk of developing EOS.

In this context, improvements in detection of intrapartum maternal infection through the use of new technologies, including microfluidic assays, amniotic fluid analyses, and real-time polymerase chain reaction in order to develop pointof-care devices that are inexpensive, fast, highly sensitive, and specialized will allow healthcare professionals to promptly determine neonates who are at risk (17).

It is also worth mentioning that the link between male sex in the neonates and EOS found here was shown to be consistent with that reported by Wang et al. (2016) (18) and Chan et al. (2013) (4). Although the mechanism between sex and sepsis is unclear, some related factors such as genes linked to the $X$ chromosome of the immune system and hormonal differences have been described in the literature (19).

In addition, even if an association between male sex and EOS was found in our study, it is nevertheless important to carry out future research, including the genetic factors that predispose someone to developing EOS, and thus enabling subsequent appropriate interventions to be carried out in this population. We also found significant relationship between the increase in hospital days for the neonates and EOS, which can be due to infections acquired in the hospital.

This investigation had limitations regarding information bias, since it was a secondary analysis of data. Additionally, data were not always entered by the same person; however, the professionals who were in charge of this task have several years of experience. Another limitation is that the results may not be extrapolated for preterm patients, since the hospital does not treat this type of neonate due to a lack of neonatal intensive care unit.

It should be also noted that the statistical analysis focused only on the existence or not of associations. Thus, it cannot define whether EOS was a predictor or a consequence of a prolonged stay in the hospital. Furthermore, all patients are referred to other institutions for treatment and management of more complex cases. Finally, it is important to take into account that HMC mainly treats military personnel and their families; therefore, this is considered a limitation in part, when extrapolating the results of this study to a larger population.

In short, we concluded that the total prevalence of EOS at HMC in 2009-2017 was 4.8\%. The neonatal factors associated with EOS were male sex and longer hospital stay. Maternal factors associated with EOS were greater gestational age and development of urinary tract infection in the third trimester of pregnancy. This study is the first on EOS in children of Peruvian military personnel and it should be used as precedent for new studies in this field.

\section{REFERENCES}

1. Cortese $F$, Scicchitano $P$, Gesualdo $M$, et al. Early and late infections in newborns: where do we stand? a review. Pediatr Neonatol. 2016;57(4):265-73. https://doi.org/10.1016/j.pedneo.2015.09.007 PMid:26750406

2. Wynn JL. Defining neonatal sepsis. Curr Opin Pediatr. 2016;28(2):135-40. https://doi.org/10.1097/MOP. 0000000000000315 PMid:26766602 PMCid:PMC4786443

3. Kimberlin DW, et al. Red Book 2015: 2015 Report of the Committee on Infectious Diseases, American Academy of Pediatrics. 2015.

4. Chan GJ, Lee AC, Baqui AH, Tan J, Black RE. Risk of early-onset neonatal infection with maternal infection or colonization: a global systematic review and meta-analysis. PLoS Med. 2013;10(8):e1001502. https://doi.org/10.1371/journal.pmed.1001502 PMid:23976885 PMCid:PMC3747995

5. Gebremedhin D, Berhe H, Gebrekirstos K. Risk factors for neonatal sepsis in public hospitals of Mekelle city, North Ethiopia, 2015: unmatched case control study. PLoS One. 2016;11(5):e0154798. https://doi.org/10.1371/journal.pone.0154798 PMid:27163290 PMCid:PMC4862626 
6. Rojas Espinoza ES. Factores determinantes de sepsis neonatal temprana en el Hospital Nacional Dos de Mayo, enero-diciembre 2012 [research work] [online]. Lima: Universidad Nacional Mayor de San Marcos, Facultad de Medicina Humana Escuela de Post-Grado; 2014. Available from: https://pdfs.semanticscholar.org/a896/ 0947a4e5e1936224b14216161166d6e9cc67.pdf [Accessed 10 August 2019].

7. Fleischmann-Struzek C, Goldfarb DM, Schlattmann P, Schlapbach $\amalg$, Reinhart K, Kissoon N. The global burden of paediatric and neonatal sepsis: a systematic review. Lancet Respir Med. 2018;6(3):223-30. https://doi.org/10.1016/S2213-2600(18)30063-8

8. Wynn JL, Wong HR, Shanley TP, Bizzarro MJ, Saiman L, Polin RA. Time for a neonatal-specific consensus definition for sepsis. Pediatr Crit Care Med. 2014;15(6):523-8. https://doi.org/10.1097/PCC.0000000000000157 PMid:24751791 PMCid:PMC4087075

9. Jiang Z, Ye GY. 1:4 matched case-control study on influential factor of early onset neonatal sepsis. Eur Rev Med Pharmacol Sci. 2013;17(18):2460-6. PMID: 24089224

10. Daniel Enrique RC. Factores de riesgo maternos asociados a sepsis neonatal temprana en prematuros en el servicio de neonatología del Hospital María Auxiliadora en el periodo enero- diciembre 2015 [dissertation] [online]. Lima: Universidad Ricardo Palma, Facultad de Medicina Humana; 2017. Available at: http://cybertesis.urp.edu.pe/bitstream/urp/1007/1/Rivera\%20Ch\%C3\%A1vez\%20Daniel\%20Enrique_2017.pdf [Accessed 30 October 2018].

11. Pérez RO, Lona JC, Quiles M, Verdugo MÁ, Ascencio EP, Benítez EA. Early neonatal sepsis, incidence and associated risk factors in a public hospital in western Mexico. Rev Chilena Infectol. 2015;32(4):387-92. https://doi.org/10.4067/S0716-10182015000500003 PMID: 26436790

12. Coral Linares KM. Factores de riesgo asociados a sepsis neonatal precoz en el Hospital Vitarte durante el periodo 2011-2013 [research work] [online]. Lima: Universidad Nacional Mayor de San Marcos, Facultad de Medicina Humana Escuela de Post-Grado; 2014. Available from: https://pdfs.semanticscholar.org/8603/a82939e16a791f b16176fd72eaf74d3031bf.pdf [Accessed 30 October 2018].

13. Jajoo M, Kapoor K, Garg LK, Manchanda V, Mittal SK. To study the incidence and risk factors of early onset neonatal sepsis in an out born neonatal intensive care unit of India. J Clin Neonatol. 2015;4(2)91-5. https://doi.org/10.4103/2249-4847.154106

14. Softić I, Tahirović H, Di Ciommo V, Auriti C. Bacterial sepsis in neonates: single centre study in a Neonatal intensive care unit in Bosnia and Herzegovina. Acta Med Acad. 2017;46(1):7-15. https://doi.org/10.5644/ama2006-124.181 PMid:28605923

15. Ministry of Health of Peru. Guías nacionales de atención integral de la salud sexual y reproductiva. 2004. Available at: http://bvs.minsa.gob.pe/local/dgsp/63_guiasnac.pdf

16. Iyo Alberti FL. Controles prenatales y puntaje Apgar menor de 7 como factores determinantes de sepsis neonatal temprana. Hospital Nacional Dos de Mayo [research work]. Trujillo: Universidad Privada Antenor Orrego, Facultad de Medicina Humana Escuela Profesional de Medicina Humana; 2015. Available at: http://repositorio.upao.edu.pe/bitstream/upaorep/1590/1/zavaleta_Medina_Prenatales_Apgar_Sepsis.pdf [Accessed 30 October 2018].

17. Chan GJ, Lee AC, Baqui AH, Tan J, Black RE. Prevalence of early-onset neonatal infection among newborns of mothers with bacterial infection or colonization: a systematic review and meta-analysis. BMC Infect Dis. 2015;15:118. https://doi.org/10.1186/s12879-015-0813-3 PMid:25886298 PMCid:PMC4364328

18. Wang ME, Patel AB, Hansen NI, Arlington L, Prakash A, Hibberd PL. Risk factors for possible serious bacterial infection in a rural cohort of young infants in central India. BMC Public Health. 2016;16(1):1097. https://doi.org/10.1186/s12889-016-3688-3 PMid:27760543 PMCid:PMC5070173

19. Guidet B, Maury E. Sex and severe sepsis. Crit Care. 2013;17(3):144. https://doi.org/10.1186/cc12690 PMid:23680409 PMCid:PMC3672659

$\diamond \diamond \diamond \diamond \diamond \diamond \diamond$

http://www.ejgm.co.uk 